\title{
Histological comparison of infectious hematopoietic necrosis virus challenged juvenile rainbow trout Oncorhynchus mykiss and coho salmon $O$. kisutch gill, esophagus/cardiac stomach region, small intestine and pyloric caeca
}

\author{
Consetta M. Helmick ${ }^{1}$, J. Franklin Bailey ${ }^{2}$, Scott LaPatra ${ }^{3}$, Sandra Ristow ${ }^{1, *}$ \\ ${ }^{1}$ Department of Animal Sciences, Washington State University, Pullman, Washington 99164, USA \\ ${ }^{2}$ Electron Microscopy Center, University of Idaho, Moscow, Idaho 83843, USA \\ ${ }^{3}$ Clear Springs Foods, Inc., PO Box 712 , Buhl, Idaho 83316, USA
}

\begin{abstract}
A histological evaluation of selected tissues from juvenile rainbow trout Oncorhynchus mykiss and coho salmon $O$. kisutch was conducted. Morphological differences between the 2 species were detected in gills, esophagus/cardiac stomach region (ECSR), small intestine and pyloric caeca at the light microscopy and ultrastructural levels. With respect to gill architecture, only the coho salmon exhibited a dilation of the afferent filamental artery termed an ampulla or 'bleb' Gills of both species exhibited differences in the distribution of mucous and chloride cells, and the size and orientation of pillar and endothelial cells varied. The esophageal/cardiac stomach region of the 2 species differed with respect to the epithelial cell architecture of the mucosa and the appearance and location of mucussecreting (acinar type) serous cardiac glands (MSSG) in the submucosa. The small intestine mucosa of the 2 species also differed, with the coho salmon exhibiting columnar vacuolated absorptive cells, whereas the rambow trout exhibited columnar nonvacuolated absorptive cells. Juveniles of both species were challenged in vivo with a virulent isolate of infectious hematopoietic necrosis virus or mockchallenged with phosphate buffered saline. The most notable tissue response produced by exposure to the virus was observed in the ECSR and occurred as early as 1 h post viral challenge. At $24 \mathrm{~h}$, MSSG and ECSR epithelial tissue of rainbow trout exhibited severe intercellular edema with separation of the mucosal and glandular epithelia, whereas minimal changes were observed in the coho MSSG. Marked changes were also noted at $24 \mathrm{~h}$ in the ECSR epithelial cells of coho salmon. At $24 \mathrm{~h}$ post virus exposure, the virus appeared to have had no pathologic effect on the gills, small intestine or pyloric caeca in either species.
\end{abstract}

KEY WORDS: Rhabdoviruses - Rainbow trout - Coho salmon Morphology Histology

\section{INTRODUCTION}

In the Pacific Northwest of the United States, infectious hematopoietic necrosis virus (IHNV) is the most devastating disease of cultured salmonids, particularly rainbow trout Oncorhynchus mykiss, including steelhead (Pilcher \& Fryer 1980, Trust 1986). As aquacul-

\footnotetext{
·Addressee for correspondence. E-mail: ristow@wsu.edu
}

ture production expands, so do losses to disease. IHNV was first detected in hatchery-reared sockeye salmon in Washington State by Rucker et al. (1953), but has subsequently been detected in other salmonid species, such as chum (dog) salmon $O$. keta, amago $O$. rhodurus, yamame (cherry) salmon $O$. masou and sockeye (blueback) salmon O. nerka (Kimura \& Awakura 1977). Recently, the virus has been isolated from adult coho salmon $O$. kisutch, a species previously considered to be resistant (LaPatra et al. 1989). 
Literature on the morphology at the light microscopic and ultrastructural levels of gill and digestive tract tissues of IHNV-challenged juvenile rainbow trout Oncorhynchus mykiss and coho salmon $O$. kisutch is not extensive; however, several morphological studies have been conducted on the normal gill and digestive tract tissues of adult rainbow trout $O$. mykiss, Atlantic salmon Salmo salar, chinook salmon $O$. tschawytscha and brown trout S. trutta (Greene 1911, Weinreb \& Bilstad 1955, Burnstock 1959, Bullock 1963, Ezeasor \& Stokoe 1981, Yasutake \& Wales 1983, Olsen 1991).

IHNV has been found budding from adult rainbow trout gill epithelium $9 \mathrm{~d}$ post viral challenge (Yamamoto \& Clermont 1990), and virus titers have been measured in adult sockeye salmon Oncorhynchus nerka gills (Mulcahy et al. 1983). Recently, IHNV was detected in gills of steelhead trout during pre-epizootic and epizootic disease outbreaks in experimentally challenged fish (Drolet et al. 1994). Yasutake \& Wales (1983) demonstrated involvement of eosinophilic granule cells located in the esophagus/cardiac stomach region (ECSR) in naturally infected adult rainbow trout. Smith (1989) reported generalized necrosis of small intestine eosinophilic granule cells in acute IHNV infection in adult rainbow trout. However, these eosinophilic granule cells are absent in rainbow trout alevin and small fry (Bolton 1933, Kimura \& Kudo 1975). Interestingly, IHNV does not appear to possess the same virulence in all salmonids. In vitro and in vivo studies have shown that coho salmon and their triploid hybrids, as well as cell lines derived from coho salmon. are much more resistant to IHNV challenges than are rainbow trout and their derived cell lines (de Kinkelin et al. 1974, Ord et al. 1976, Lannan et al. 1984, Parsons et al. 1986, Chen et al. 1990).

This study examined selected morphological characteristics of juvenile rainbow trout and coho salmon gill, ECSR, small intestine and pyloric caeca at the light microscopic and ultrastructural levels. In the present study, the early response to IHNV in selected juvenile fish tissues of the rainbow trout and coho salmon was examined.

\section{MATERIALS AND METHODS}

Virus and fish viral challenges. The 220-90 isolate of IHNV used in this study was obtained from commercially raised rainbow trout at Clear Springs Foods, Inc. (Buhl, ID, USA) (LaPatra et al. 1991). Eight groups of 5 juvenile (0.32 g mean weight) stock rainbow trout $O n-$ corhynchus mykiss were obtained from Clear Springs Foods, Inc. Domsea stock juvenile coho salmon $O$. kisutch $(0.5 \mathrm{~g}$ mean weight) were obtained from AquaSeed (Rochester, WA). All fish were fasted 3 d prior to challenge with $10^{5}$ plaque-forming units (pfu) $\mathrm{ml}^{-1}$
IHNV isolate 220-90 or mock-challenged with phosphate buffered saline (PBS) pH 7.0. Challenged groups were housed in separate 221 aquaria which received ultraviolet-disinfected, single-pass springwater at a constant water temperature $\left(15^{\circ} \mathrm{C}\right)$ prior to, during and post challenge. In vivo immersion challenges of the fish with IHNV isolate 220-90 were conducted in a closed system by exposing fish for $1 \mathrm{~h}$. Following challenge, fish were removed at 1 and $24 \mathrm{~h}$, anesthetized in MS-222, and submerged in $6 \%$ paraformaldehyde containing $0.5 \%$ glutaraldehyde in 0.1M PBS ( $\mathrm{pH} 7.2$ ) fixative for $15 \mathrm{~min}$. After the fish expired, a ventral midline incision through the abdomen was made to further expose internal organs to fixative, whereupon the whole fish was rinsed twice in 0.1M PBS ( $\mathrm{pH} 7.2$ ), placed in fresh fixative and stored at $4^{\circ} \mathrm{C}$. All subsequent tissue processing was performed at room temperature, including processing for transmission electron microscopy

Processing for TEM. Four juvenile rainbow trout Oncorhynchus mykiss and 4 juvenile coho salmon $O$. kisutch were randomly removed at 1 and $24 \mathrm{~h}$ post IHNV challenge and processed for TEM. Four randomly selected $24 \mathrm{~h}$ post mock challenge fish from each species were also processed in the same manner. Fish were dissected after fixation, and samples of gill, ECSR, pyloric caeca and small intestine were rinsed in $0.1 \mathrm{M}$ PBS $(\mathrm{pH} 7.0)$ overnight at $4^{\circ} \mathrm{C}$. Tissues were processed for TEM by an ethanol dehydration series $(40,50,70,80,95$ and $100 \%$ ) (10 min each), followed by a $50: 50$ mixture of $100 \%$ ethanol to propylene oxide infiltration for $15 \mathrm{~min}$. Samples were then exposed to $100 \%$ propylene oxide for $15 \mathrm{~min}$. Finally, samples were exposed to a 50:50 mixture of propylene oxide to Medcast medium grade epoxy (Ted Pella, Redding, CA, USA) for infiltration, rotating overnight at room temperature. (Note: To preserve antigenicity, tissue was not exposed to osmium tetroxide preembedding stain.) The samples were then embedded in Medcast medium-grade epoxy and cured for $24 \mathrm{~h}$ at $50^{\circ} \mathrm{C}$. Parallel thick sections ( 1 to $2 \mu \mathrm{m}$ ) were cut with an LKB (model 8800 Ultrotome III) ultramicrotome, using a glass knife to obtain parallel sections from $24 \mathrm{~h}$ post mock and 1 and $24 \mathrm{~h}$ post IHNV-challenged rainbow trout and coho salmon tissue. Thin sections (100 to $200 \mathrm{~nm}$ ) were cut, using a Dupont diamond knife, and mounted on non-coated 300-mesh nickel grids. Sections were post stained with uranyl acetate for $8 \mathrm{~min}$, rinsed with distilled water, air dried and examined with a Zeiss EM 10A transmission electron microscope or a Hitachi 600 transmission electron microscope.

\section{RESULTS}

Tissue examined included gills, ECSR pyloric caeca and small intestines. 
Gill

Several structural differences were noted between rainbow trout and coho salmon at the light microscopic and ultrastructural. levels. At the ultrastructural level, a number of differences were observed between the 2 species, such as secondary lamellae tip thickness appears greater in rainbow trout (Fig. 1B), dilation of the afferent filamental artery, termed an ampulla or 'bleb' in coho salmon (Fig. 1C), mucous and chloride

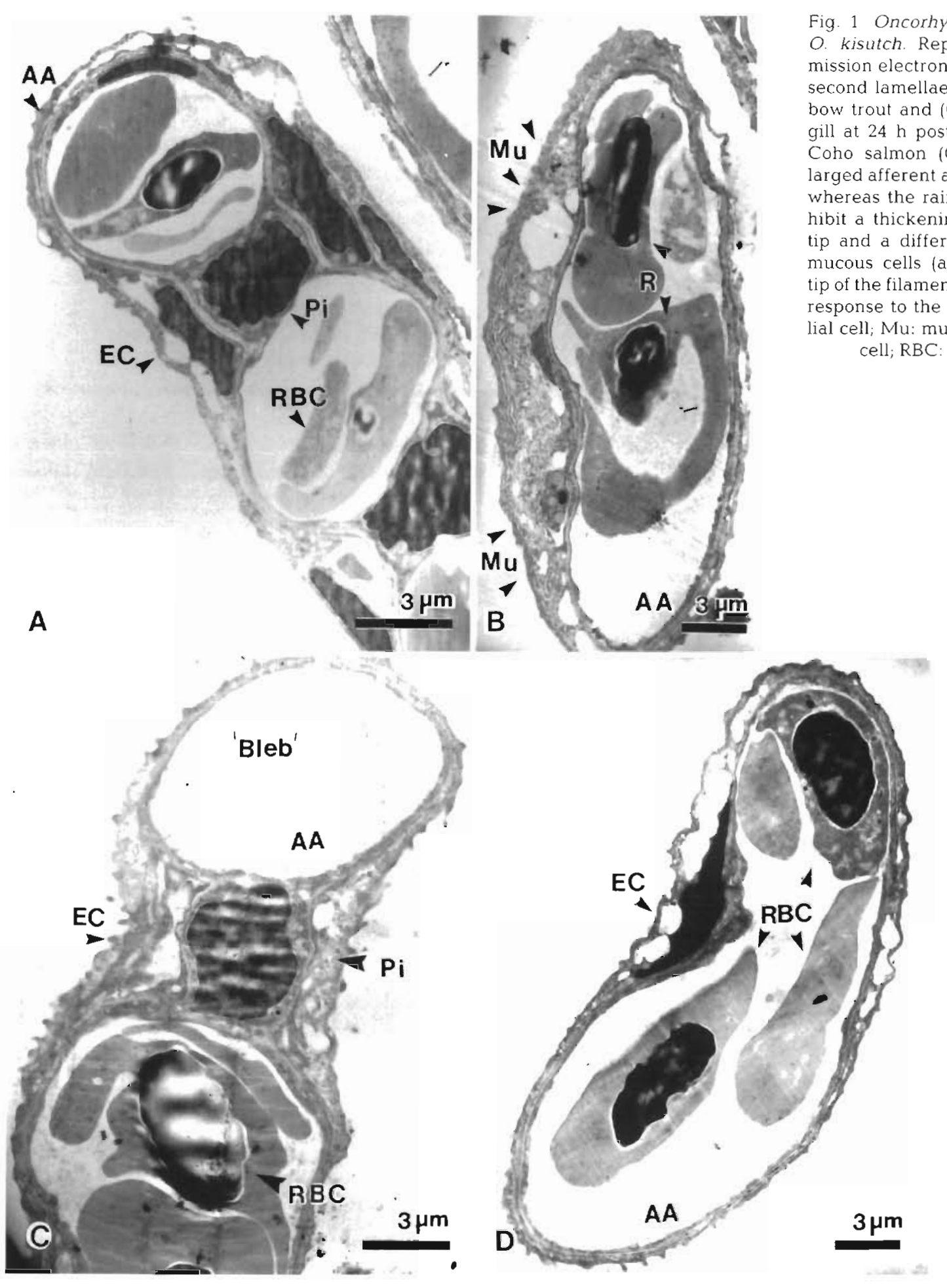


cell distribution, and the size and orientation of pillar and endothelial cells were noted (Fig 1).

In addition, rainbow trout and coho salmon were challenged in vivo with IHNV, and their gills subsequently evaluated for structural changes induced by the virus. The gross histology of both the IHNVchallenged or mock-challenged gill tissue indicated no pathologic changes due to the virus challenge at either the 1 or 24 h time points (Fig. 1).

\section{ECSR}

A combination of mucus-secreting glands and serous cardiac glands were detected in the transitional area between the esophagus and cardiac stomach (ECSR). Structural differences in the ECSR were noted between the rainbow trout and coho salmon at both the light microscopic and ultrastructural levels. At the light microscopy level, the mucosa of the ECSR differs between the 2 species, particularly with respect to the epithelial cells in the mucosa and the appearance and orientation of submucosal mucussecreting serous cardiac glands (MSSG) (Fig. 2). In rainbow trout, MSSG are found opposite the swim bladder pneumatic duct (Fig. 2B) forming long continuous glands in the submucosa associated with the mucosal lumen (Fig. 3A, C). In contrast, the coho salmon MSSG are located posterior to the swim bladder pneumatic duct (Fig. 2F) and bud from the basilar mucosal epithelial cells. These form a dense, compact unit in the submucosa which does not connect to the mucosal lumen (Fig. 3E, G).

When ECSR tissue from mock-challenged and IHNV-challenged rainbow trout and coho salmon were compared, a cystic degeneration appeared in the MSSG of both species challenged with IHNV (Fig. 3C, $D, H)$. In contrast, the ECSR tissue from the IHNVchallenged coho salmon appeared unaffected by the virus at $1 \mathrm{~h}$ (Fig. 3F); however, similar but less severe changes were seen at $24 \mathrm{~h}$ (Fig. 3H). At the ultrastructural level, the most severe lesions were observed at $24 \mathrm{~h}$ post IHNV challenge (Fig. 4). Both the rainbow trout and coho salmon epithelial cells exhibited interstitial tissue separation (Fig. 4A, B) and cystic degeneration of the MSSG (Fig, 4C, D). No pathologic changes were seen in the ECSR or MSSG of either the mock-challenged rainbow trout or coho salmon at either the light microscopic (Fig. 3A, E) or ultrastructural levels (Fig. 5).

\section{Small intestine and pyloric caeca}

At both the light microscopic and ultrastructural levels, the luminal epithelium of the small intestine differed between the 2 species; the mucosa of the rainbow trout had columnar nonvacuolated absorptive cells (Fig. 6A), whereas the coho salmon had large numbers of columnar vacuolated absorptive cells (Fig. 6B).

Juvenile rainbow trout and coho salmon small intestine and pyloric caeca, whether from mock-challenged or 1 or 24 h post IHNV challenge, fish appeared similar (Fig. 6). Following viral exposure, no influx of immune cells, such as 'wandering' lymphocytes or enteroepithelial leukocytes was noted (Fig. 6).

The pancreatic acinar-type cells located between fingers of the pyloric caeca were structurally unique for rainbow trout (Fig. $7 \mathrm{~A}, \mathrm{~B}$ ) and coho salmon (Fig. 7C, D) and appeared morphologically similar to the MSSG of the ECSR. Unlike the MSSG of the ECSR, the pancreatic acinar-type cells exhibited no pathologic changes from exposure to IHNV at either 1 or $24 \mathrm{~h}$ post challenge.

\section{DISCUSSION}

Distinct morphological differences in the gills, ECSR small intestine and pyloric caeca at the light microscopic and ultrastructural levels were detected in all tissues examined from both rainbow trout and coho salmon.

\section{Gill}

In general, the gill architecture was similar in the 2 species, with the exception of a few morphological differences, such as the distribution of mucous and chloride cells, the size and orientation of pillar and endothelial cells and the expression of an afferent artery 'bleb' in coho salmon. The function of the 'bleb' is not known, but it has been speculated that it may be

Fig. 2. Oncorhynchus mykiss and $O$. kisutch. Line diagram shows the location of the esophagus/cardiac stomach region (ECSR) and the swim bladder pneumatic duct in relationship to other anatomical structures in rainbow trout and coho salmon. Representative light micrographs of the ECSR of $(A-C)$ rainbow trout and (D-F) coho salmon show the location of the mucus-secreting serous cardiac glands (MSSG) $24 \mathrm{~h}$ post IHNV challenge. Rainbow trout: (A) pre-pneumatic duct, no MSSG present; (B) opposite pneumatic duct, appearance of $\mathrm{MSSG}_{i}(\mathrm{C})$ post-pneumatic duct, increased density of MSSG. Coho salmon: (D) pre-pneumatic duct, no MSSG present; (E) opposite pneumatic duct, no MSSG present; (F) post-pneumatic duct, appearance of MSSG 

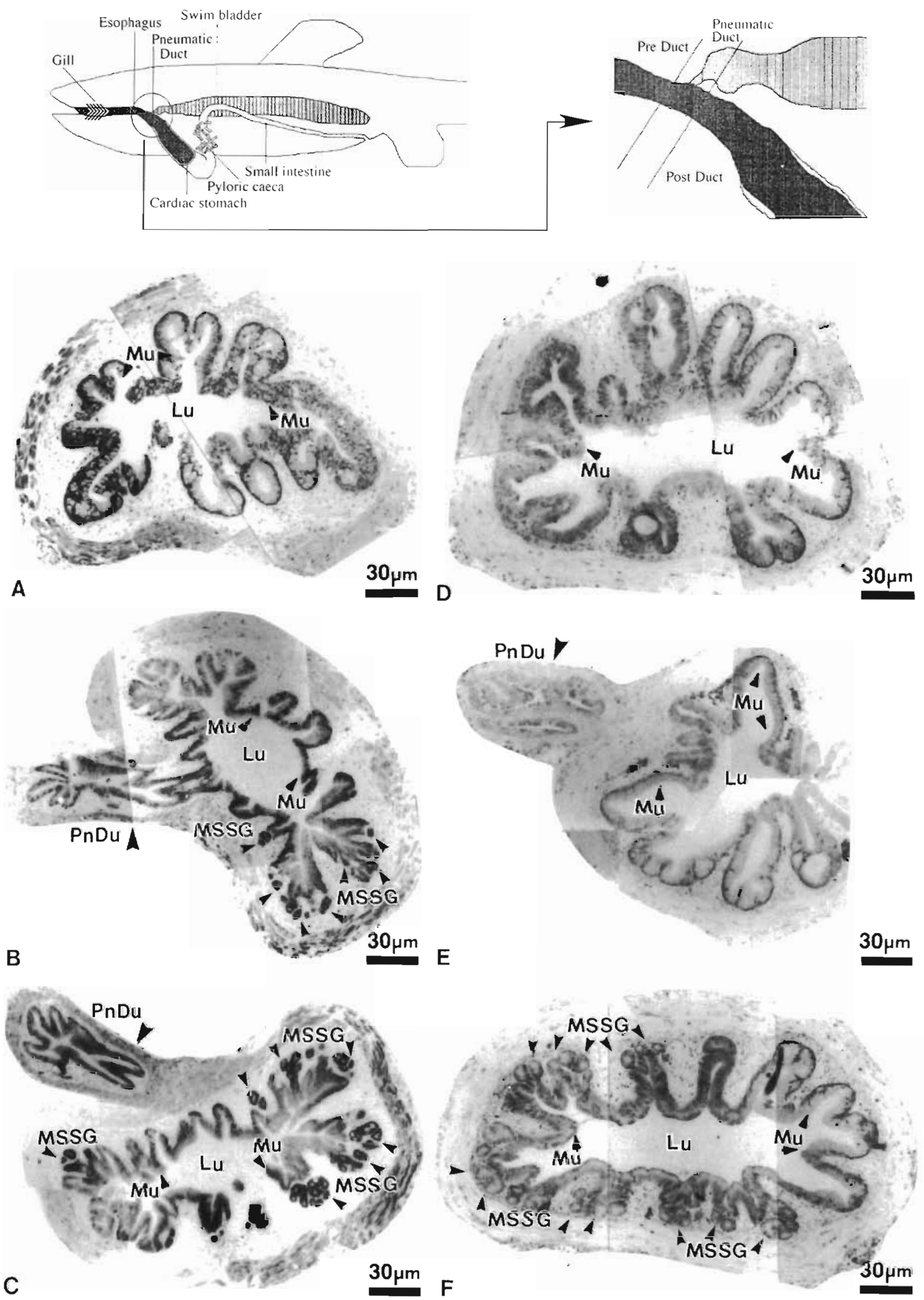


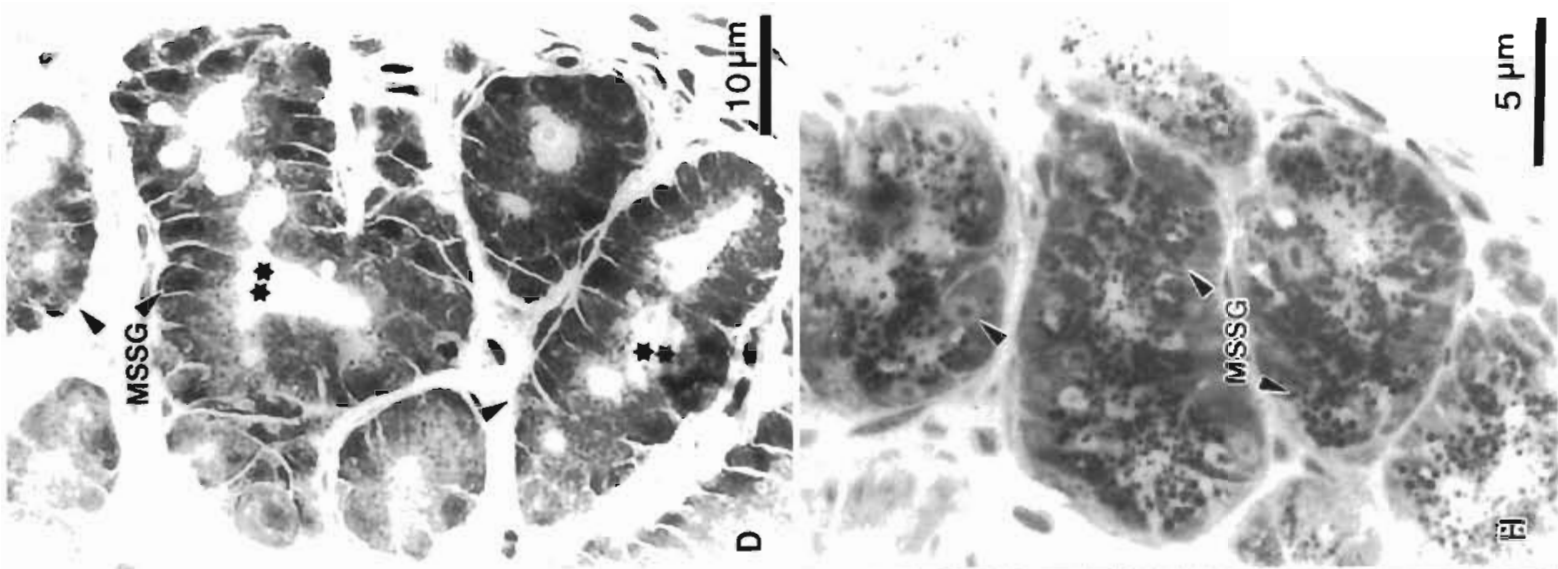

1)

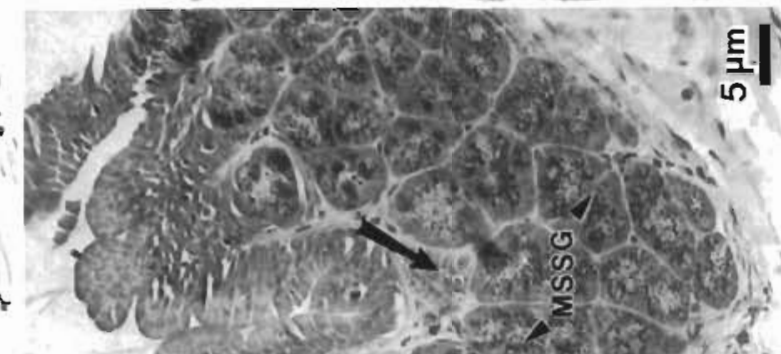

튼

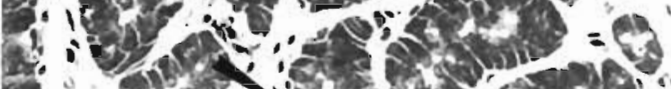

- tow $y$ ind

P.

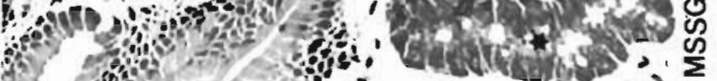
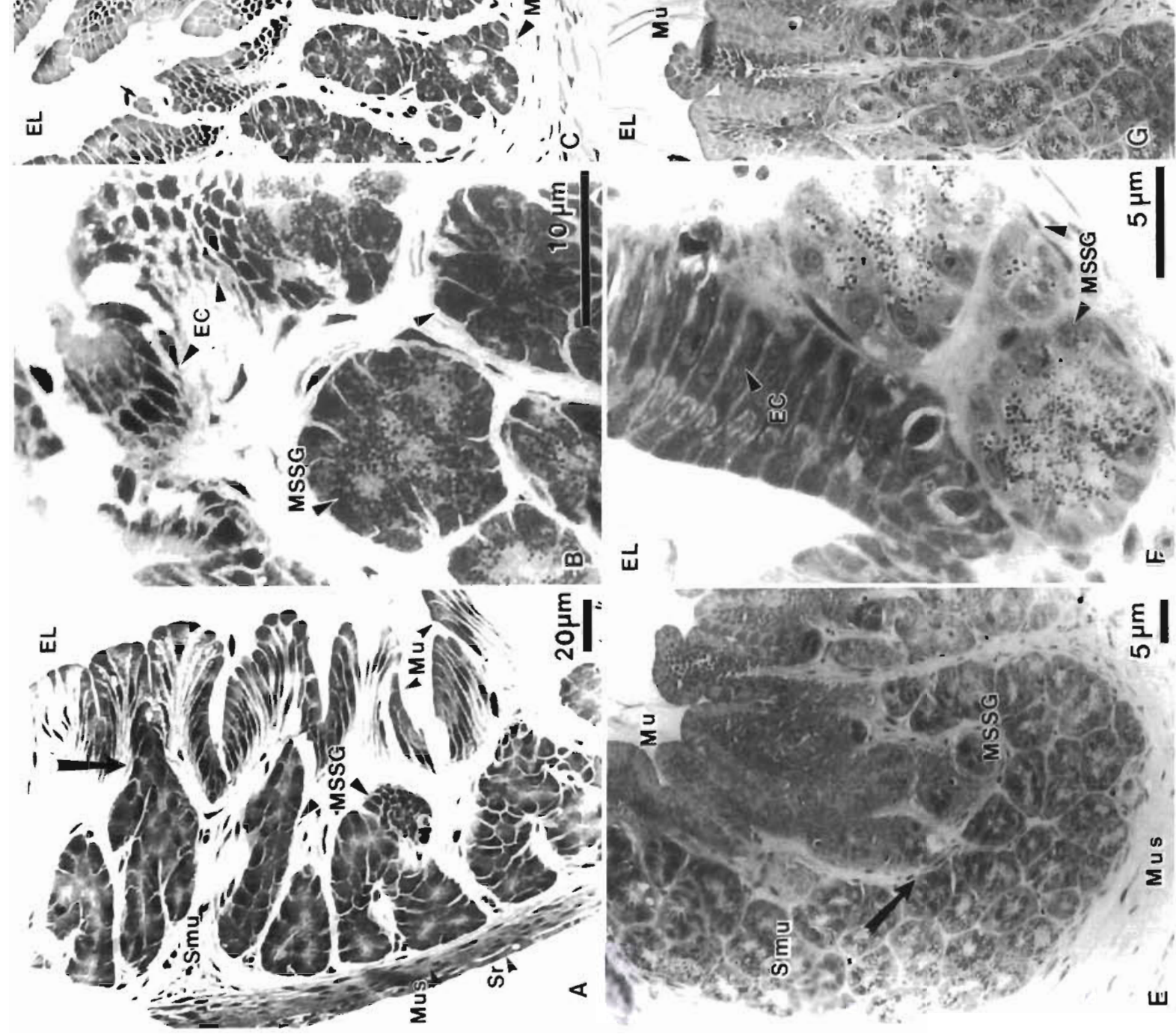

部 


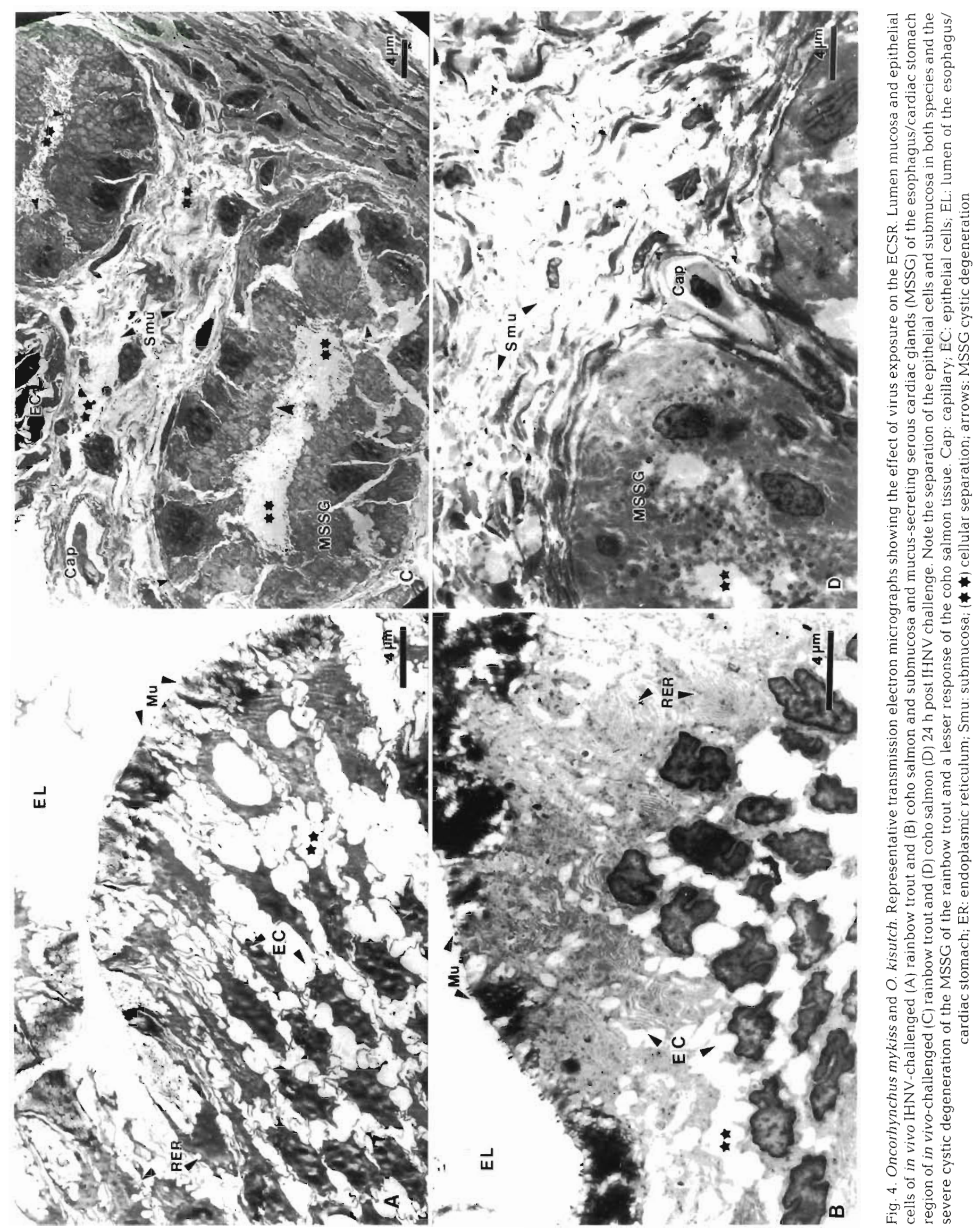




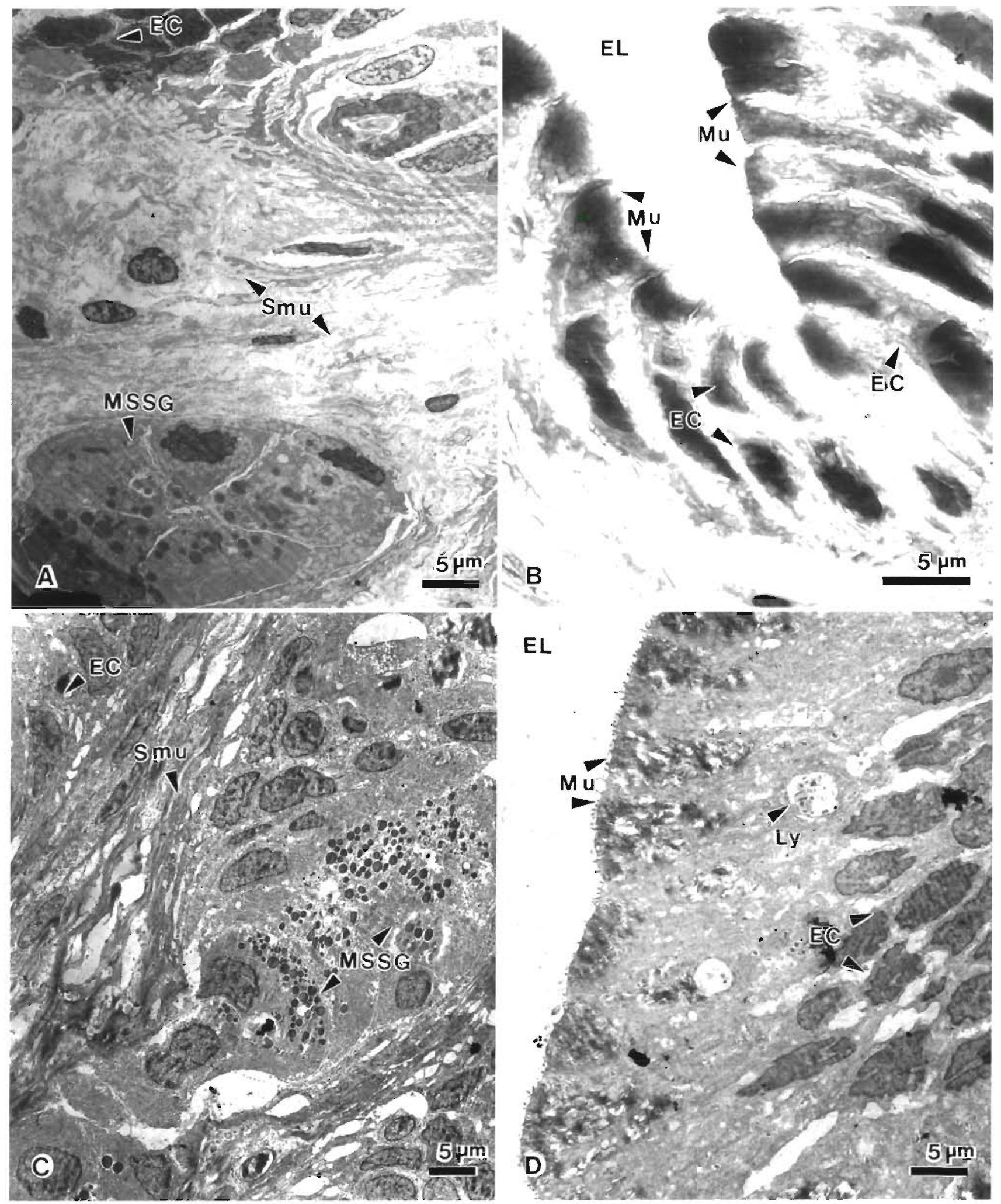

Fig 5 Oncorhynchus mykiss and $O$ kısutch Representative transmission electron micrographs comparing the ECSR lumen, mucosa. submucosa. epithelial cells and mucus-secreting serous cardiac glands (MSSG) $24 \mathrm{~h}$ post mock challenge in (A, B) rainbow trout and $(C, D)$ coho salmon. Note the healthy and intact appearance of this tissue. EC: epithelial cells; EL: esophagus/ cardiac stomach lumen, Ly. lysosome; Mu mucous cell, Smu submucosa 


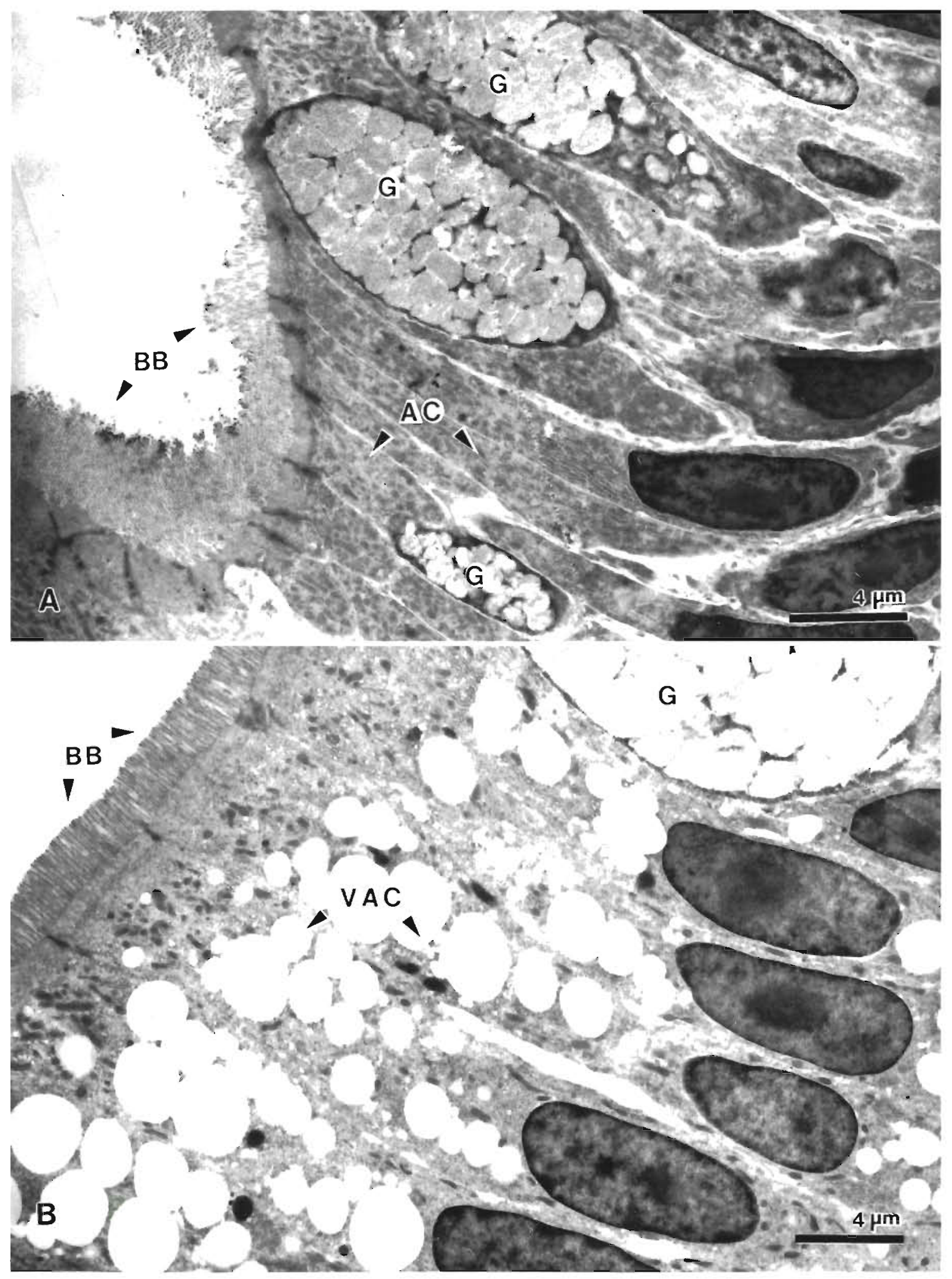

Fig. 6. Oncorhynchus mykiss and $O$. kisutch Representative transmission electron micrographs of the (A) rainbow trout and (B) coho salmon small intestinal lumen at $24 \mathrm{~h}$ post IHNV challenge All in vivo challenged rainbow trout or coho salmon small intestine, whether $24 \mathrm{~h}$ mock challenge or 1 and $24 \mathrm{~h}$ post IHNV challenge, exhubited no pathologic changes AC: nonvacuolated absorptive cells; BB. brush border; G. goblet cell; VAC: vacuolated absorptive cell 

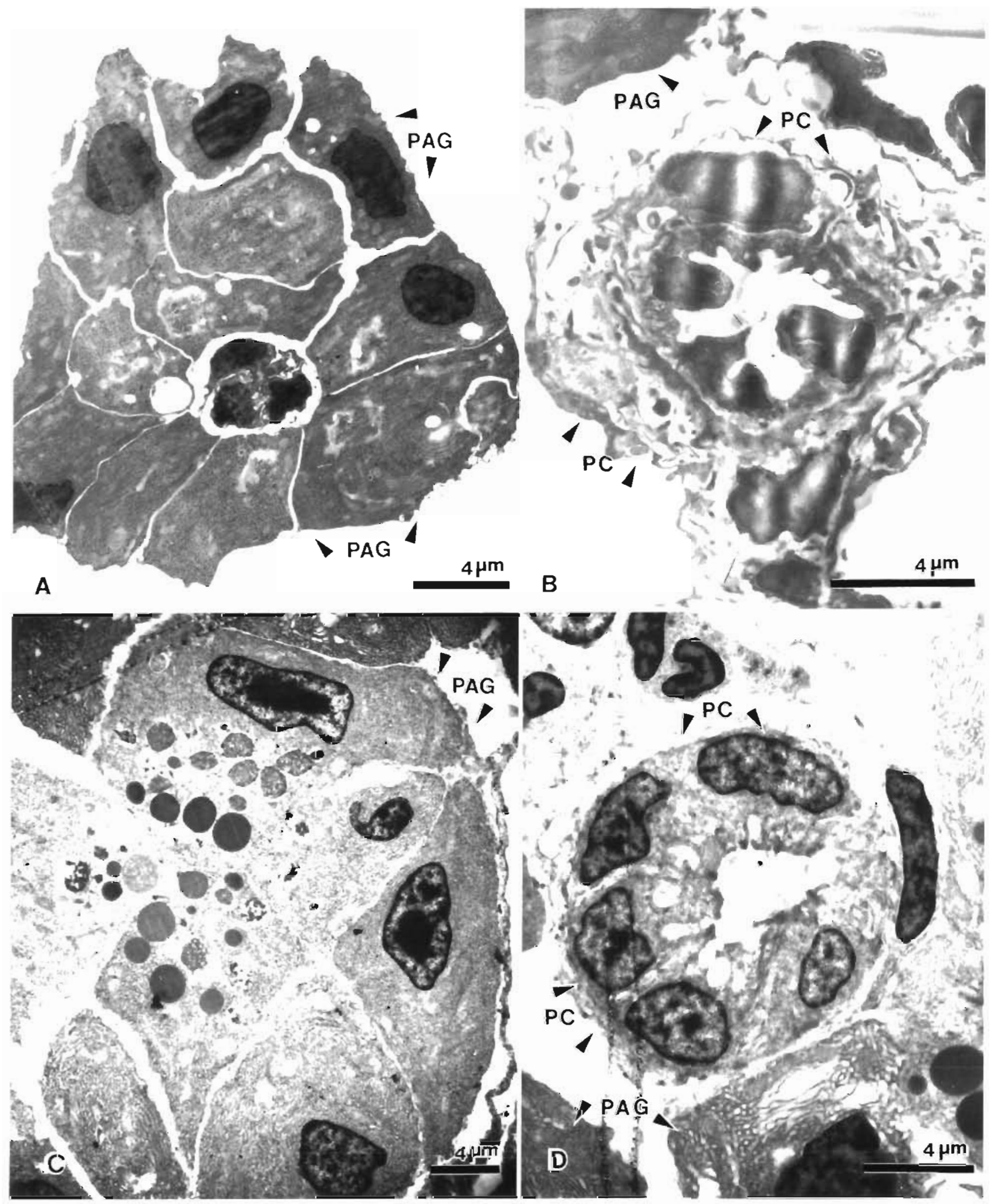

Fig. 7 Oncorhynchus mykiss and $O$ kısutch. Representative transmissıon electron micrograph of rainbow trout (A) pancreatic acinar-type cells and (B) pylonc caeca finger and coho salmon (C) pancreatıc acinar-type cells and (D) pyloric caeca finger at $24 \mathrm{~h}$ post IHNV challenge All in vivo challenged rambow trout or coho salmon pancreatic acinar-type cells and pyloric caeca, whether $24 \mathrm{~h}$ mock challenge or 1 and $24 \mathrm{~h}$ post IHNV challenge, exhubited no pathologic changes. PAG: pancreatic gland; 
involved in boosting arterial pressure (Fromm 1974, Hughes 1984), or it may be an evolutionary relic of the elasmobranch body (Laurent 1984). In both species, the entire gill branchial complex is covered with epithelial cells consisting of unspecialized cells, chloride and mucous cells. The unspecialized cells are thought to be involved in protection and support of the gill (Yasutake \& Wales 1983). Each lamella is constructed with a series of interconnecting spaces, separated and supported by pilaster (pillar) cells.

Since the gill is comprised of such a large, delicate epithelium that is constantly exposed to potentially pathogen-rich water, it is considered to be an important portal of entry for micro-organisms, such as bacteria, protozoa and virus (Ferguson 1986). Gills have also been implicated as the site of entry for certain rhabdoviruses, such as spring viremia in carp (Ahne 1978) and viral hemorrhagic septicemia of rainbow trout (Chilmonczyk \& Monge 1980, Neukirch 1984). Chilmonczyk \& Monge (1980) intracardiac-injected and waterbath-challenged fish with viral hemorrhagic septicemia virus (VHSV) to determine if the gills were a portal of entry. In their study, intracardiac-injected VHSV-coated latex particles were detected within $24 \mathrm{~h}$ in the pillar cells, but waterbath-challenged fish did not express virus in the pillar cells until $3 \mathrm{~d}$ post challenge.

In the present study, histological changes in gill structure of the pillar cells of either juvenile rainbow trout or coho salmon were not observed within the first $24 \mathrm{~h}$ post IHNV challenge. Several other investigators, however, have detected IHNV in gill tissue at later time intervals. Yamamoto \& Clermont (1990) detected IHNV budding from gill filaments of rainbow trout $9 \mathrm{~d}$ post in vivo infection, and Mulcahy et al. (1983) reported an increase in IHNV titers in infected gills of sockeye salmon at $14 \mathrm{~d}$ post infection. These investigators noted that virus remained localized in sockeye salmon gill tissue without appearing in the visceral organs, suggesting that resistance mechanisms in the gills of the host may cope with an infection and limit its spread. By incorporating an alkaline phosphatase immunohistochemistry (APIH) technique at the light microscopy level, Drolet et al. (1994) demonstrated IHNV in the gills of steelhead fry $2 \mathrm{~d}$ post infection. In the present study, with the aid of an electron microscope, IHNV was not detected in the gills within the first $24 \mathrm{~h}$ post challenge in either fish species examined. Additionally, no pathologic response was observed in the gill that may have resulted from exposure to virus.

\section{ECSR}

The ECSR is one of the least studied organs in fish. Most fish have a short, wide esophagus which provides mucous for lubrication of food and facilitating transport from the mouth to the stomach. The esophagus also serves as a transitional area between the striated muscles of the mouth and the smooth muscles of the stomach (Smith 1989). Most fish have numerous mucous cells located in the posterior end of the esophagus and anterior end of the cardiac stomach region which have been implicated in digestive processes (Reifel \& Travill 1977).

The overall morphology of the juvenile rainbow trout and coho salmon ECSR exhibited similar characteristics to those found in other salmonids as well as mammals. Fish and mammalian esophagi are comprised of 4 'typical' cell layers: the mucosa, the submucosa, the muscularis and the serosa (Weinreb \& Bilstad 1955). The mucosal surface is comprised of large undulating mucosal-lined folds which differentiate into secondary folds containing 2 types of glands: the mucus-secreting glands and serous glands, which in fish are referred to as serous cardiac glands (Yasutake \& Wales 1983). In the adult rainbow trout, the mucus-secreting glands are located anterior to the swim bladder pneumatic duct, and the serous cardiac glands are posterior to the duct, with no glands being located at the duct entrance (Weinreb \& Bilstad 1955). In this study, a combination of mucussecreting and serous cardiac glands was found in the transitional area of the esophagus/cardiac region. (MSSG). In rainbow trout, MSSG are located in the submucosa just opposite the swim bladder pneumatic duct and appear to form a long continuous gland in conjunction with the esophageal/cardiac stomach mucosa. In the coho salmon, the MSSG are located posterior to the pneumatic duct, appearing to bud from the mucosal lumen, thus forming dense clusters in the submucosa.

Only a few pathologic changes have been documented in the fish ECSR. Ferguson et al. (1986) described a severe muscular degenerative myopathy of the Atlantic salmon esophagus caused by a vitamin E deficiency which impedes the ability of the fish to swallow food pellets. Ezeasor \& Stokoe (1980) demonstrated the presence of eosinophilic granule cells in the stratum compactum and granulosum of adult rainbow trout esophagus and cardiac stomach. These cells are thought to have an immune function and have been described in IHNV-infected adult rainbow trout (Yasutake \& Wales 1983); however, these eosinophilic granule cells appear to be absent in rainbow trout alevin and small fry (Bolton 1933, Kimura \& Kudo 1975). It is thought that the eosinophilic granule cells develop with maturity and upon exposure to different diets. No eosinophilic granule cells were detected in either juvenile rainbow trout or coho salmon in the present study. 
In this study, a major pathologic change was observed between the IHNV-challenged ECSR MSSG and epithelial cells of rainbow trout and coho salmon. As early as 1 h post IHNV challenge, rainbow trout MSSG became cystic; then by $24 \mathrm{~h}$ post IHNV challenge, the surrounding submucosal tissue separated, and the MSSG exhibited severe cystic degeneration. Whether the damage to the luminal epithelia and MSSG was virally induced or was a secondary response to inflammatory mediators is presently unknown. In contrast, coho salmon tissue appeared resistant to the virus at 1 h post challenge, but at $24 \mathrm{~h}$, changes were noted in the epithelial cells and MSSG, similar to those exhibited by the rainbow trout.

\section{Small intestine and pyloric caeca}

Teleosts exhibit a vast diversity in the form and function of their digestive tracts. This diversity is influenced by the age of the animal, the type of food ingested and the amount of surface area needed to achieve maximum absorption. To maximize nutrient absorption, some fish have evolved elongated intestinal tracts consisting of elaborate folding, coiling, internal ridging and the addition of pyloric caeca (Smith 1989). The luminal surface of the intestinal tract is lined by columnar epithelial cells with a brush border comprised of a microvilli similar to that found in mammals, except that fish do not possess an internal blood supply or lymphatic ducts (Jilek 1979). Bullock (1963) determined that the intestinal tracts of adult Atlantic salmon, chinook salmon, rainbow trout and brown trout Salmo trutta were morphologically similar. Juvenile rainbow trout and coho salmon exhibited the 'typical' fish intestine comprised of 4 cell layers: the mucosa, submucosa, muscularis and serosa. The mucosa is composed of at least 2 epithelial cell types: goblet cells, which produce mucous for lubrication and protection; and/or columnar vacuolated and nonvacuolated absorptive cells which are involved in protein and lipid absorption. Only columnar nonvacuolated absorptive cells were found in the rainbow trout intestine, while only vacuolated absorptive cells were found in the coho salmon intestinal tracts in this study. Even though columnar vacuolated absorptive cells were shown in adult rainbow trout, none were detected in juvenile rainbow trout; however, they may develop with maturity.

Immune cells, such as small 'wandering' lymphocytes, and polymorphonuclear cells (Bullock 1963) and other granulocytes, which are located in the connective tissue of the submucosa (Blake 1936, Weinreb \& Bilstad 1955, Krementz \& Chapman 1975), were found in both species. No influx of leucocytes was observed in either species following pathogen challenge, which would indicate a rapid response of the fish immune system toward the pathogen. Unlike the findings of Smith (1989), who showed an acute necrosis of eosinophilic granule cells in the submucosa of adult rainbow trout, no pathological changes were manifested in juvenile rainbow trout or coho salmon small intestine after viral challenge. Other salmonid viruses, such as infectious pancreatic necrosis virus (IPNV), promote severe sloughing of epithelial cells of the intestinal mucosa of rainbow trout (Roberts 1978), while VHSV causes a rapid systemic haemorrhagic response of the submucosa (Horlyck et al. 1984).

The pyloric caeca, blind finger-like extensions of the ascending intestine which are located posterior to the stomach, exhibited distinct morphological differences between the 2 species. The epithelium of the pyloric caeca is similar to the ascending intestine, except for an increased number of cells dedicated to fat absorption (Greene 1911) and the presence of small apical lysosomal bodies (Ezeasor \& Stokoe 1981). The pancreatic tissue of salmonids is scattered within the mesenteric adipose tissue attached to the pyloric caeca and consists of 2 cell types: pancreatic acinar type (exocrine) cells; and scattered islet cells (endocrine) (Weinreb \& Bilstad 1955). Even though the exocrine pancreatic acinar-type glands and the ECSR MSSG (acinar-type gland) appear morphologically similar for each species, they responded differently to IHNV exposure. Pancreatic acinar-type glands showed no pathologic change to virus exposure in either species; however, rainbow trout ECSR (MSSG) acinar-type cells exhibited a severe cystic degeneration following IHNV challenge.

In summary, a number of basic morphological differences between rainbow trout and coho salmon were noted: differences in the mucus-producing cells of the gill lamella; the presence of an ampulla or 'bleb' at the afferent artery of the coho salmon; differences in the location and type of mucus-secreting serous cardiac glands present in the ECSR; the type of columnar vacuolated or nonvacuolated absorptive cell present in the small intestine; and the unique pancreatic and ECSR acinar-type glands of each species. The only tissue in either species exhibiting an early pathologic change to viral exposure was the esophagus/cardiac mucussecreting glands and epithelial cells, with the rainbow trout exhibiting the most severe reaction. We speculate that the ECSR and MSSG is a portal of entry for the virus in both species, and that morphological differences between the 2 species might partially explain the differences in susceptibility to IHNV.

Acknowledgments. The authors thank Jerry Jones of Clear Springs Foods, Inc, and Dr Tom Baldwin of the Washington Animal Disease Diagnostic Laboratory for their excellent 
technical assistance. This is scientific paper no. 8098 from the College of Agriculture and Home Economics Research Center of Washington State University. This material is based upon work supported by the cooperative state research service United States Department of Agriculture through the Western Regional Aquaculture Center under agreement numbers 93-38500-8588 and 94-38500-0049. This work was supported by USDA CSRS Special Aquaculture Grant 90-34123-5138.

\section{LITERATURE CITED}

Ahne W (1978) Uptake and multiplication of spring virema of carp virus in carp (Cyprinus carpio L.). J Fish Dis 1. $265-268$

Blake IH (1936) Studies on the comparative histology of the digestive tube of certain teleost fishes. J Morph 60:77-112

Bolton LL (1933) Basophile (mast) cells in the alimentary canal of Salmonid fishes. J Morph 54:549-582

Bullock WL (1963) Intestinal histology of some salmonid fishes with particular reference to the histopathology of acanthocephalan infections. J Morph 112:23-34

Burnstock G (1959) The morphology of the gut of the brown trout (Salmo trutta). J Micro Sci 100:183-198

Chen MF, Aikens CM, Fryer JL, Rohovec JS (1990) Virulence of four isolates of infectious hematopoietic necrosis virus in salmonid fishes and comparative replication in salmonid fish cell lines. Calif Fish Game 76:137-145

Chilmonczyk S, Monge D (1980) Rainbow trout gill pillar cells: demonstration of inert particles, phagocytosis and involvement in viral infection. J Reticuloendothel Soc 28:327-333

de Kinkelin P, LeBerre M. Meurillon A, Calmels M (1974) Septicemie hemmorrhagique virale: demonstration de l'etat refractaire du saumon coho (Oncorhynchus kisutch) et de l'truite fario (Salmo trutta). Bull Fr Pisic 253:166-176

Drolet BS, Rohovec JS, Leong JC (1994) The route of entry and progression of infectious hematopoietic necrosis virus in Oncorhynchus mykiss: a sequential Immunohistochemical study. J Fish Dis 17:337-348

Ezeasor DN, Stokoe WM (1981) Light and electron microscopic studies on the absorptive cells of the intestine, caeca and rectum of the adult rainbow trout (Salmo gairdneri Richardson). J Fish Biol 18:527-544

Ferguson HW, Roberts RJ, Richards RH, Collins RO, Rice DA (1986) Severe degenerative cardiomyopathy associated with pancreatic disease in Atlantic salmon (Salmo salar L.). J Fish Dis 9:95-98

Fromm PO (1974) Circulation in trout gills: pressure of 'blebs' in afferent filamental vessels. J Fish Res Bd Can 31: $1793-1796$

Greene CW (1911) The absorption of fats by alimentary tract, with special reference to the function of the pyloric caeca in the king salmon (Oncorhynchus tschawytscha). Trans Am Fish Soc 41:261-270

Horlyck V, Mellegard S, Dalsgaard I, Vestergaard-Jørgensen PE (1984) Occurrence of VHS in Danish maricultured rainbow trout. In: Roberts RJ (ed) Fish pathology. Bailliere Tindall, London, p 214

Hughes GM (1984) General anatomy of the gills. In: Hoar WS, Randall DJ (eds) Fish physiology, Vol. XA. Academic Press, New York, p 1-72

Jilek R (1979) Intestinal histology of Dorosoma cepedianum. J Fish Biol 14:125-126

Kimura T. Awakura T (1977) Studies on viral diseases of Japanese fishes. VI. Infectious hematopoietic necrosis (IHN) of salmonids in the mainland of Japan. J Tokyo Univ Fish 63:920-924
Kimura N, Kudo S (1975) Fine structure of the stratum granulosum of the pyloric caeca of the rainbow trout. Japan $J$ Ichthyol 22:16-22

Krementz AB, Chapman GB (1975) Ultrastructure of the posterior half of the intestine of the channel catfish (Ictalurus punctatus). J Morph 145:441-482

Lannan CN, Winton JR, Fryer JR (1984) Fish cell lınes: establishment and characterization of nine cell lunes from salmonids. In Vitro 20:671-676

LaPatra SE, Fryer JL, Wingfield WH, Hedrick RP (1989) Infectious hematopoietic necrosis virus in coho salmon (Oncorhynchus kisutch). J aquat Anim Health 1:277-280

LaPatra SE, Lauda KA, Morton AW (1991) Antigenic and virulence comparison of isolates of infectious hematopoietic necrosis virus from the Hagerman Valley, Idaho, USA. In: Proceedings of the second international symposium on viruses of lower vertebrates. Oregon State University Press, Corvallis, p 125-129

Laurent P (1984) Gill internal morphology. In: Hoar WS, Randall DJ (eds) Fish physiology, Vol. XA. Academic Press, New York, p 73-183

Mulcahy DM, Pascho JR, Jenes CK (1983) Detection of infectious hematopoietic necrosis virus in river water and demonstration of water-borne transmission. J Fish Dis 6:321-330

Neukirch M (1984) An experimental study of the entry and multiplication of viral haemorrhagic septicemia virus in rainbow trout (Salmo gairdneri Richardson) after waterborne infection. J Fish Dis 7:231-234

Olsen KH (1991) Vasculature of the fish gill: anatomical correlates of physiological functions. J Elect Micro Tech 19: $389-405$

Ord WM, LeBerre M, de Kinkelin P (1976) Viral hemorrhagic septicemia: comparative susceptibility of rainbow trout (Salmo gardneri) and hybrids (Salmo gairdneri $x$ Oncorhynchus kisutch) to experimental infection. J Fish Res Bd Can 33:1205-1208

Parsons JE, Busch RA, Thorgaard GH, Scheerer PD (1986) Increased resistance of triploid rainbow trout $x$ coho salmon hybrids to infectious hematopoietic necrosis virus Aquaculture 57:337-343

Pilcher KS, Fryer JL (1980) The viral diseases of fish: a review through 1978. Part 1: Disease of proven viral etiology CRC Crit Rev Microbiol 7(4):287-364

Reifel CW, Travill AA (1977) Structure and carbohydrate histochemistry of the esophagus in ten teleostean species. J Morph 152:303-314

Roberts RJ (1978) The pathophysiology and systemic pathology of teleosts. In: Roberts RJ (ed) Fish pathology. Bailliere Tindall, London, p 51-91

Rucker RJ, Wipple WJ, Parvin JR, Evans CA (1953) A contagious disease of salmon possibly of virus origin. US Fish Wildl Ser Fish Bull 54(76):35-46

Smith L (1989) Digestive functions in teleost fishes. In: Halver $\mathrm{J}$ (ed) Fish nutrition, 2nd edn. Academic Press, New York, p 331-397

Trust TJ (1986) Pathogenesis of infectious diseases of fish. A Rev Microbiol 40:479-502

Weinreb EL, Bilstad NM (1955) Histology of the digestive tract and adjacent structures of the rainbow trout (Salmo gairdneri irideus). Copeia 3:194-204

Yamamoto T, Clermont TJ (1990) Multiplication of infectious hematopoietic necrosis virus in rainbow trout following immersion infection: organ assay and electron microscopy $\mathrm{J}$ aquat Anim Health 2:261-270

Yasutake WT, Wales JH (1983) Microscopic anatomy of salmonids: an atias. US Dept of the Interior, Fish and Wildlife Service Publication 150, Washington DC, p 25 